\title{
Biomarkers for hepatocellular carcinoma: progression in early diagnosis, prognosis, and personalized therapy
}

\author{
Kai Zhu ${ }^{1,2}$, Zhi Dai ${ }^{1,2}$ and Jian Zhou ${ }^{1,2,3^{*}}$
}

\begin{abstract}
Hepatocellular carcinoma (HCC) is one of the most common malignant tumors in the world. Currently, surgical resection, liver transplantation, and local ablation are considered curative therapeutic practices for HCC. The diagnosis of HCC without pathologic confirmation is achieved by analyzing serum alpha-fetoprotein (AFP) levels combined with imaging techniques, including ultrasonography, magnetic resonance imaging, and computerized tomography. Although progress has been made in the diagnosis and management of HCC, its prognosis remains dismal. Various new technologies have identified numerous novel biomarkers with potential diagnostic as well as prognostic value, including Dickkopf-1 and Golgi protein 73 . These biomarkers not only help in the early diagnosis and prediction of prognosis, but also assist in identifying potential targets for therapeutic interventions. In this article, we provide an up-to-date review of the biomarkers that are used for early diagnosis, prognosis prediction, and personalized treatment of HCC.
\end{abstract}

Keywords: Hepatocellular carcinoma, Early diagnosis, Prognosis, Biological markers

\section{Introduction}

Hepatocellular carcinoma (HCC) is one of the most frequently diagnosed cancers worldwide. The disease is predominant in Asia and Africa, but its incidence is steadily increasing throughout the rest of the world [1]. Most HCC develop in patients with a history of chronic hepatitis or cirrhosis in which there is continuous inflammation and regeneration of hepatocytes. Unlike other solid malignancies, the coexistence of inflammation and cirrhosis makes the early diagnosis and prognostic assessment of HCC much more difficult. This complication highlights the need to identify valuable biomarkers for the diagnosis and treatment of HCC.

The proliferation and survival of cancer cells require a process called oncogene addiction, which is the activation of specific oncogenes and inactivation of specific tumor suppressors, such as Rb1 in retinoblastoma [2] and BRCA1 in breast cancer [3]. However, no specific

\footnotetext{
* Correspondence: zhou.jian@zs-hospital.sh.cn

'Liver Cancer Institute, Zhongshan Hospital, Fudan University, Shanghai 200032, China

${ }^{2}$ Key Laboratory of Carcinogenesis and Cancer Invasion, Fudan University, Ministry of Education, Shanghai 200032, China

Full list of author information is available at the end of the article
}

oncogene addictions have been observed in HCC, which is a complex disease with a variety of underlying pathogenic anomalies caused by multiple risk factors. The lack of ideal biomarkers for HCC diagnosis, prognosis, and therapy has posed a major challenge to $\mathrm{HCC}$ management.

With advances in the understanding of tumor biology, interest in identifying molecular biomarkers of $\mathrm{HCC}$ has increased. Over the last decade, a number of new cutting-edge technologies such as next-generation sequencing $[4,5]$ and microarray technologies [6-8] have emerged, leading the search for biomarkers into a new era of "omics" $[9,10]$. Using these technologies, it is now quite easy to examine a whole tumor genome (including copy number variations, loss of heterogeneity, aneuploidy, single nucleotide polymorphism) [11-14], transcriptome [15,16], proteome $[17,18]$, epigenome $[19,20]$, metabolome [21-23], and miRNA profile [24,25], and the analysis of tens of thousands of molecular targets has become affordable and operable. Currently, numerous circulating markers and tissue markers have been identified [17,26-30]; however, few biomarkers are acceptable for clinical utility because of their low predictive accuracy

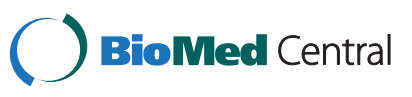


and/or high cost. Here, we provide an up-to-date review of the biomarkers that are used for early diagnosis, prognosis, and personalized treatment of $\mathrm{HCC}$.

\section{Review}

\section{Biomarkers for early diagnosis}

The diagnosis of HCC without pathologic confirmation can be achieved by assessing the serum alpha-fetoprotein (AFP) level combined with imaging techniques, including ultrasonography, magnetic resonance imaging, and computerized tomography [31,32]. However, improvement in early diagnosis is still needed because only $44 \%$ of the patients are diagnosed at a localized disease stage, and only $30 \%$ of patients with HCC are candidates for potentially curative treatments at the time of diagnosis [33]. Thus, the discovery of an effective, reliable tool for early diagnosis of $\mathrm{HCC}$ to increase the number of patients who are suitable for curative treatment will play a pivotal role in improving HCC patients' prognosis.

A marker for early diagnosis would meet the following requirements: first, it should achieve high accuracy, which would increase the probability of a diagnosis being made prior to spread and thus increase the cure rate; second, specimen collection for detecting the marker should be easily operable and non-invasive; and third, the cost-effectiveness should be considered [34]. Tumor tissue-oriented markers are not highly practical because not all tumor tissues can be obtained at an early stage and the invasive procedure may cause spread of tumor cells. Biomarkers from body fluids such as serum, plasma, urine, and bile are suitable candidates for early diagnosis of $\mathrm{HCC}$ because they are easily accessible [35]. In the following section, we list some important circulating (serum or plasma) markers for early diagnosis of HCC.

\section{Protein}

Since AFP was discovered in the serum of HCC patients in 1964 [36], it has been regarded as the most useful serum protein thus far for patients at risk for HCC [37-39]. However, its sensitivity for detecting HCC ranges between $25 \%-60 \%[39,40]$, and its specificity is also low because serum AFP can also be detected in patients with cirrhosis (11\%-47\%) and chronic hepatitis (15\%-58\%).

In addition to AFP, more than 20 serum proteins have clinical significance in early diagnosis of HCC $[10,41]$, among which several proteins are proved to have advantages over AFP.

DKK1 DKK1 belongs to a family of secreted proteins that play an important role in HCC progression through the promotion of cytoplasmic/nuclear accumulation of beta-catenin in HCC cells via the Wnt/beta-catenin signaling pathway [42].

Recently, Shen et al. [41] reported that serum DKK1 is a promising candidate for $\mathrm{HCC}$ diagnosis. The authors retrospectively assessed serum DKK1 in 1284 patients (633 with HCC, 171 with chronic HBV infection, 168 with cirrhosis, and 312 healthy controls) and found that DKK1 has better diagnostic value for HCC than does AFP, especially for patients with AFP-negative and early stage HCC. Combined testing of serum DKK1 and AFP concentrations improved diagnostic accuracy for HCC versus all controls compared with either test alone. Nevertheless, DKK1 is not overly specific for HCC diagnosis, and a recent study reported that serum DKK1 was also elevated in patients with intrahepatic cholangiocarcinoma [43].

Golgi protein 73 (GP73) GP73 is a $73 \mathrm{kDa}$ transmembrane glycoprotein that normally resides within the Golgi complex. It is expressed in normal biliary epithelial cells whereas normal hepatocytes do not express this protein, and its expression is significantly increased in liver diseases such as HCC [44].

Serum GP73 is a valuable biomarker for patients with HCC $[45,46]$. Mao et al. [46] compared serum GP73 and AFP in 4217 participants, including 1690 healthy adults, 337 HBV carriers, 512 patients with cirrhosis, 789 patients with HCC, 61 patients with other malignant liver lesions, 206 patients with benign liver lesions and 622 patients with 14 non-liver cancers. The sensitivity and specificity of serum GP73 for HCC were $74.6 \%$ and $97.4 \%$, respectively, compared with $58.2 \%$ and $85.3 \%$ for AFP. The GP73 level significantly increased in patients with HCC compared with healthy controls, decreased following surgical resection of HCC lesions and increased with tumor recurrence. Although the control group included HBV carriers, this group lacked patients with chronic hepatitis, whereas most HCC patients have hepatitis.

Protein induced by vitamin $K$ absence or antagonist II (PIVKA-II) PIVKA-II, an abnormal prothrombin discovered in 1984, has been widely proposed to be a useful HCC biomarker [47]. Takikawa et al. [48] measured plasma levels of PIVKA-II and AFP in 628 patients with various diseases, including 253 patients with liver cirrhosis and 116 patients with HCC. PIVKA-II was detected in $54.3 \%$ of patients with HCC, and the concentration showed a positive correlation with the tumor size. As a screening test for detecting HCC, PIVKA-II yielded sensitivity and specificity values $(52.8 \%$ and $98.8 \%$, respectively) that were comparable with AFP. Beale et al. [49] assessed AFP and PIVKA-II levels in pre-treatment serum samples from 
50 patients with $\mathrm{HCC}$, and the combination of serum AFP and PIVKA-II was better for detecting HCC than using either AFP or PIVKA-II alone.

\section{Nucleic acids}

Nucleic acids, including DNA, RNA, and nucleosomes, can be detected in the circulation of patients with HCC, and changes in their levels have been associated with tumor burden and progression of malignancy [50]. In the past decade, circulating nucleic acids have been extensively studied with regard to their diagnostic significance [51-54]. For instance, plasma AFP mRNA $[28,55]$ is considered to be a diagnostic marker for HCC. Accumulating evidence has shown that microRNAs (miRNAs) play important roles in cancer initiation, propagation, and progression [56-58]. MiRNA deregulation occurs at early stages of $\mathrm{HCC}$ and increases throughout the various steps of hepatocarcinogenesis [52]. There are multiple studies on the diagnostic function of miRNA in HCC diagnosis [52,54,59]. However, the diagnostic value of miRNAs is limited by one or more of the following factors: limited number of screened miRNAs, small sample size, failure to differentiate HCC from hepatitis, and lack of independent validation.

Recently, we measured plasma miRNA expression profiles (723 miRNAs) in a large cohort of 934 participants that included healthy individuals and patients with chronic HBV infection, cirrhosis, or HBV-related HCC. We identified a miRNA panel (miR-122, miR-192, miR21, miR-223, miR-26a, miR-27a, and miR-801) that provided high diagnostic accuracy for discriminating patients with HCC from the healthy population $(\mathrm{AUC}=0.941)$ and patients with chronic HBV $(\mathrm{AUC}=0.842)$ or cirrhosis (AUC $=0.884)$. This finding led to the conclusion that the plasma miRNA panel had considerable clinical value for the early diagnosis of $\mathrm{HCC}$ and could help patients who might have otherwise missed the curative treatment window benefit from optimal therapy [54].

\section{Prognostic biomarkers}

Surgical resection, liver transplantation and local ablation are considered curative therapeutic practices for HCC. Other modalities, such as targeted therapy and transarterial chemoembolization (TACE), are palliative treatments. Despite these curative or palliative treatments, prognosis is still poor due to underlying liver diseases and the unique biology of HCC. As a result, biomarkers that better predict patients who are at higher risk of recurrence and poorer prognosis would help guide their treatment [26].

A number of biomarkers have been reported to predict the outcome of these therapies, including CD151 and CXCL5 for surgical treatment $[27,60]$, AFP and LDH for
TACE [61,62], PIVKA-II and VEGF for radiofrequency ablation (RFA) [63,64], and serum AFP and HBeAg for percutaneous ethanol injection (PEI) [65-67].

\section{Biomarkers for surgical treatment}

Surgical treatment offers a potentially curative option for HCC patients, but patients' outcomes are varied due to differing tumor characteristics. Additionally, the exact biology of HCC remains poorly understood, thus making prediction of outcome after surgical resection very difficult. The prognosis of HCC patients does not simply reflect the size and number of the tumors; instead, prognosis is affected by a complex interplay between known and unknown factors, including tumor biology, patient condition, etc. [35]. Thus, the ability to predict which patients have a poor prognosis would help to assign risk and guide surgery and other treatments.

Circulating biomarkers Circulating biomarkers are still preferred for prognostic prediction because they are easily accessible. Serum AFP is commonly used for diagnosis and surveillance of HCC $[37,39]$ and has been suggested as an independent indicator for prognosis. HCC patients with a high serum AFP level tend to have shorter survival $[38,53]$.

Other circulating factors such as Ang2 [53], VEGF $[53,68,69]$, HGF $[70,71]$, and TGF-beta [72], are also independent factors for HCC prognosis. A recent study proposed that plasma macrophage migration inhibitory factor (MIF) levels have prognostic value in HCC patients. Plasma MIF levels have a significant association with overall survival (OS) and disease-free survival (DFS) of HCC patients, even in patients with normal serum AFP levels and Tumor Node Metastasis (TNM) stage I HCC [73].

Circulating tumor cells (CTCs) may reflect tumor aggressiveness and serve as a promising candidate for predicting tumor recurrence and metastasis [74]. However, their utility is limited due to the rarity of CTCs in peripheral blood of the patients. Recent technical advances have made it possible to detect CTCs; therefore, their clinical value has been tested in multiple tumor types, including breast cancer [75], lung cancer [76], and prostate cancer [77]. Sun et al. proved that EpCAM-positive CTCs may serve as a prognostic marker in HCC after curative resection [78].

Tumor tissue biomarkers Research into tumor tissues can provide direct biological information about the tumors; thus, the search for tumor biomarkers is crucial. A plethora of HCC tumor cell-derived biomarkers with potential prognostic significance have been identified in recent decades $[9,17,26,35,79-81]$, but consensus could not be reached. 
HCC-related proteins have been extensively explored for use in determining prognosis [9-11,82]. For instance, our previous study investigated CXCL5 (epithelial neutrophil-activating peptide-78) expression in a large cohort of 919 HCC patients. The results showed that overexpression of CXCL5 was well correlated with intratumoral neutrophil infiltration and that CXCL5 overexpression alone or in combination with the presence of intratumoral neutrophils was an independent prognostic indicator for OS and cumulative recurrence in HCC patients [60]. In addition, our institute also searched extensively for prognostic biomarkers in HCC patients undergoing liver transplantation [17,83]. By investigating tumor tissues of $232 \mathrm{HCC}$ patients, we identified calpain small subunit 1 (Capn4) as an independent prognostic factor for recurrence and survival in HCC patients after liver transplantation [17].

Cancer stem cells (CSCs) may play a pivotal role in the progression of tumors $[84,85]$. CSCs represent the tumorigenic cells that generate tumors via the stem cell processes of self-renewal and differentiation. CSCs may persist in tumors as a distinct population and cause relapse and metastasis by giving rise to new tumors [86]. Although the existence of CSCs in HCC is still controversial, several studies have demonstrated the clinical significance of CSC markers in HCC patients [10,79]. These markers include CD90 [87], CD133 [29], CD13 [88], and EpCAM [89].

The role of the microenvironment surrounding tumor cells for the initiation and progression of HCC is becoming increasingly clear [30,90-92]. The tumor microenvironment, also named the tumor stroma, includes the extracellular matrix (ECM) and all other non-tumor cell types within a tumor tissue (e.g. endothelial cells, fibroblasts, and cells of the immune system). Various tumor stroma-associated factors, such as regulatory $\mathrm{T}$ cells (Tregs) [93], macrophage colony-stimulating factor (M-CSF) [94], macrophages [95], and hepatic stellate cells [96], have been investigated and exhibit significant prognostic value. For instance, Budhu et al. [97] showed that a unique inflammation/immune response-related signature in the venous metastasis-associated liver microenvironment coincides with elevated expression of M-CSF and can serve as a superior predictor of HCC venous metastases when compared with other clinical prognostic parameters.

\section{Biomarkers for TACE}

Although patients with early stage HCC have the chance to undergo curative treatment, most HCC patients are still diagnosed at a late stage when curative treatment is no longer applicable. For these patients, based on randomized, controlled clinical trials, TACE may be an effective treatment option for reducing systemic toxicity, increasing local antitumor effects, and improving survival $[98,99]$. However, there are markedly diverse outcomes after TACE in terms of treatment response and survival. Therefore, identifying markers that can predict TACE treatment outcomes before choosing this treatment option is an important endeavor.

The most promising prognostic candidates for TACE are circulating biomarkers. Some studies have reported that serum AFP [61], circulating nucleosomes [100], blood neutrophil-to-lymphocyte ratio [101], and lactate dehydrogenase [62], are prognostic factors for TACE. As an example, Wang et al. [61] retrospectively studied the survival of 441 HCC patients (including 139 patients with normal AFP levels and 302 patients with elevated AFP levels) after TACE, and found that patients with normal AFP levels had a better treatment response and prognosis after TACE than patients with elevated AFP levels.

\section{Personalized therapy}

The recent discovery of new therapeutic targets based on the molecular pathways that are involved in hepatocarcinogenesis has led to exciting results in targeted treatment of HCC patients. Investigators have attempted to select therapeutic options for patients according to their tumor's molecular profile, and this treatment modality will pave the way for personalized treatment of HCC.

\section{Targeted therapy}

Targeted therapy that specifically inhibits molecular abnormalities has emerged as an effective therapeutic option for malignancies [102,103]. Small molecule tyrosine kinase inhibitors have great potential for the treatment of HCC through targeting several growth factors and their associated signaling pathways (e.g. EGF/EGFR, VEGF/VEGFR, IGF/IGFR, PDGF, FGF, RAS/RAF/ERK/MAPK, PI3K/AKT/mTOR, Wnt/betacatenin) [104,105]. Currently, nearly 60 reagents are being investigated for treatment of $\mathrm{HCC}$, but only sorafenib have been proven effective in patients with advanced HCC [106].

Sorafenib is an oral multi-kinase inhibitor that competitively inhibits ATP binding to the catalytic domains of various kinases, such as Raf kinase, VEGFR-2, -3, and PDGFR, thereby increasing apoptosis and decreasing angiogenesis and cell proliferation [79,106,107]. However, no specific marker can guide the use of sorafenib in HCC; in contrast, HER2 and EGFR expression can positively predict the therapeutic response rate of trastuzumab in breast cancer and cetuximab in non-small cell lung cancer, respectively. 
Other oral tyrosine-kinase inhibitors including sunitinib, linifanib, brivanib, and regorafenib block a number of angiogenesis-related signaling pathways, such as VEGFR, PDGFR, and FGFR [35,104,107]. Although many clinical trials have been discontinued because of poor effectiveness or severe adverse effects, these approaches provide critical insight into the mechanisms of targeted therapy for HCC and may finally allow us to optimize the current therapies for this fatal disease.

\section{Interferon-alpha}

Interferon-alpha is a multifunctional cytokine that postpones recurrence of $\mathrm{HCC}$ and improves OS in HCC patients after curative resection [108-110]. However, the benefit of interferon-alpha therapy is usually modest because it is not effective for all patients, and it is difficult to determine which patients will respond well to interferon-alpha $[108,111]$. A recent study analyzed the miRNA profiles of 455 patients with HCC who had undergone curative tumor resection and assessed the association of the miRNA profiles with survival and response to therapy with interferon-alpha. The study showed that HCC patients whose tumors express low levels of miR-26 have a better response to interferonalpha therapy than patients with high levels, suggesting that miR-26 expression status could be used as a predictor of the response to interferon-alpha therapy [112]. At present, a multicenter, randomized controlled trial assessing the impact of low miR-26 expression on interferon-alpha adjuvant therapy for HCC patients is ongoing in China (NCT01681446, http://clinicaltrials. gov/ct2/show/NCT01681446?term=jia+fan\&rank=3).

\section{Conclusions}

New technologies have identified numerous novel biomarkers with potential diagnostic and prognostic value. Recent advances in identification, isolation, and capture of tumor-derived microvesicles will reveal new insights into HCC diagnosis and personalized therapy [113]. Nevertheless, most of these markers have been studied retrospectively; few prospective trials have evaluated their clinical significance, or clinical application.

Because HCC is a complex disease with multiple underlying pathogenic mechanisms caused by a variety of risk factors, it is difficult to characterize HCC with a single biomarker. Thus, signatures of a combination of biomarkers may be more valuable for the diagnosis, staging, and prognosis of HCC. In the near future, identifying non-invasive and cost-effective biomarkers for early diagnosis and personalized treatment of HCC will be one of the most promising fields of biomarker research.

\section{Abbreviations}

HCC: Hepatocellular carcinoma; AFP: Alpha-fetoprotein; GP73: Golgi protein 73; PIVKA-II: Protein induced by vitamin $\mathrm{K}$ absence or antagonist II; miRNA: microRNA; TACE: Transarterial chemoembolization;

RFA: Radiofrequency ablation; PEI: Percutaneous ethanol injection; MIF: Migration inhibitory factor; OS: Overall survival; DFS: Disease-free survival; TNM: Tumor Node Metastasis; CTC: Circulating tumor cell; Capn4: Calpain small subunit 1; CSC: Cancer stem cell; ECM: Extracellular matrix;

Treg: Regulatory T cell; M-CSF: Macrophage colony-stimulating factor.

\section{Competing interests}

The authors declare that they do not have anything to disclose regarding funding from industries or conflict of interest with respect to this manuscript.

\section{Authors' contributions}

ZK drafted the manuscript. All authors read and approved the final manuscript.

\section{Grant support}

This study was jointly supported by the National Key Sci-Tech Special Project of China (Grant No. 2012ZX10002-016), National Science Fund for Distinguished Young Scholars (81225019) and National Natural Science Funds of China (No. 812250125; No. 81172277; No. 81272724).

\section{Author details}

'Liver Cancer Institute, Zhongshan Hospital, Fudan University, Shanghai 200032, China. ${ }^{2}$ Key Laboratory of Carcinogenesis and Cancer Invasion, Fudan University, Ministry of Education, Shanghai 200032, China. ${ }^{3}$ Shanghai Key Laboratory of Organ Transplantation, Zhongshan Hospital, Fudan University, Shanghai 200032, China

Received: 27 October 2012 Accepted: 2 February 2013

Published: 5 February 2013

\section{References}

1. Jemal A, Bray F, Center MM, Ferlay J, Ward E, Forman D: Global cancer statistics. CA Cancer J Clin 2011, 61:69-90.

2. Sachdeva UM, O'Brien JM: Understanding pRb: toward the necessary development of targeted treatments for retinoblastoma. J Clin Invest 2012, 122:425-434.

3. Miki Y, Swensen J, Shattuck-Eidens D, Futreal PA, Harshman K, Tavtigian S, Liu Q, Cochran C, Bennett LM, Ding W, et al: A strong candidate for the breast and ovarian cancer susceptibility gene BRCA1. Science 1994, 266:66-71.

4. Cho W, Ziogas DE, Katsios C, Roukos DH: Emerging personalized oncology: sequencing and systems strategies. Future Oncol 2012, 8:637-641.

5. Meyerson M, Gabriel S, Getz G: Advances in understanding cancer genomes through second-generation sequencing. Nat Rev Genet 2010, 11:685-696.

6. Bostjancic E, Zidar N, Glavac D: MicroRNA microarray expression profiling in human myocardial infarction. Dis Markers 2009, 27:255-268.

7. Leivonen SK, Makela R, Ostling P, Kohonen P, Haapa-Paananen S, Kleivi K Enerly E, Aakula A, Hellstrom K, Sahlberg N, Kristensen VN, Borresen-Dale AL, Saviranta P, Perala M, Kallioniemi O: Protein lysate microarray analysis to identify microRNAs regulating estrogen receptor signaling in breast cancer cell lines. Oncogene 2009, 28:3926-3936.

8. Dexlin L, Ingvarsson J, Frendeus B, Borrebaeck CA, Wingren C: Design of recombinant antibody microarrays for cell surface membrane proteomics. J Proteome Res 2008, 7:319-327.

9. Aravalli RN, Steer CJ, Cressman EN: Molecular mechanisms of hepatocellular carcinoma. Hepatology 2008, 48:2047-2063.

10. Marquardt JU, Galle PR, Teufel A: Molecular diagnosis and therapy of hepatocellular carcinoma (HCC): an emerging field for advanced technologies. J Hepatol 2012, 56:267-275.

11. Villanueva A, Newell P, Chiang DY, Friedman SL, Llovet JM: Genomics and signaling pathways in hepatocellular carcinoma. Semin Liver Dis 2007, 27:55-76.

12. Kumar V, Kato N, Urabe Y, Takahashi A, Muroyama R, Hosono N, Otsuka M, Tateishi R, Omata M, Nakagawa H, Koike K, Kamatani N, Kubo M, Nakamura Y, Matsuda K: Genome-wide association study identifies a susceptibility 
locus for HCV-induced hepatocellular carcinoma. Nat Genet 2011, 43:455-458.

13. Krawczyk M, Mullenbach R, Weber SN, Zimmer V, Lammert F: Genome-wide association studies and genetic risk assessment of liver diseases. Nat Rev Gastroenterol Hepatol 2010, 7:669-681.

14. You JS, Jones PA: Cancer genetics and epigenetics: two sides of the same coin. Cancer Cell 2012, 22(1):9-20.

15. Hoshida Y, Nijman SM, Kobayashi M, Chan JA, Brunet JP, Chiang DY, Villanueva A, Newell P, Ikeda K, Hashimoto M, Watanabe G, Gabriel S, Friedman SL, Kumada H, Llovet JM, Golub TR: Integrative transcriptome analysis reveals common molecular subclasses of human hepatocellular carcinoma. Cancer Res 2009, 69:7385-7392.

16. Scott KL, Nogueira C, Heffernan TP, van Doorn R, Dhakal S, Hanna JA, Min C, Jaskelioff M, Xiao Y, Wu CJ, Cameron LA, Perry SR, Zeid R, Feinberg T, Kim M, Vande Woude G, Granter SR, Bosenberg M, Chu GC, Depinho RA, Rimm $\mathrm{DL}$, Chin L: Proinvasion metastasis drivers in early-stage melanoma are oncogenes. Cancer Cell 2011, 20(1):92-103.

17. Bai DS, Dai Z, Zhou J, Liu YK, Qiu SJ, Tan CJ, Shi YH, Huang C, Wang Z, He YF, Fan J: Capn4 overexpression underlies tumor invasion and metastasis after liver transplantation for hepatocellular carcinoma. Hepatology 2009, 49:460-470.

18. Dai Z, Zhou J, Qiu SJ, Liu YK, Fan J: Lectin-based glycoproteomics to explore and analyze hepatocellular carcinoma-related glycoprotein markers. Electrophoresis 2009, 30:2957-2966

19. Gao W, Kondo Y, Shen L, Shimizu Y, Sano T, Yamao K, Natsume A, Goto Y, Ito M, Murakami H, Osada H, Zhang J, Issa JP, Sekido Y: Variable DNA methylation patterns associated with progression of disease in hepatocellular carcinomas. Carcinogenesis 2008, 29:1901-1910.

20. Um TH, Kim H, Oh BK, Kim MS, Kim KS, Jung G, Park YN: Aberrant CpG island hypermethylation in dysplastic nodules and early HCC of hepatitis $B$ virus-related human multistep hepatocarcinogenesis. J Hepatol 2011 54:939-947.

21. Claudino WM, Quattrone A, Biganzoli L, Pestrin M, Bertini I, Di LA: Metabolomics: available results, current research projects in breast cancer, and future applications. J Clin Oncol 2007, 25:2840-2846.

22. Ward PS, Thompson CB: Metabolic reprogramming: a cancer hallmark even warburg did not anticipate. Cancer Cell 2012, 21:297-308.

23. Zhang $A$, Sun $H$, Wang $X$ : Power of metabolomics in diagnosis and biomarker discovery of hepatocellular carcinoma. LID. Hepatology 2012, doi:10.1002/hep.26130

24. Varnholt H, Drebber U, Schulze F, Wedemeyer I, Schirmacher P, Dienes HP, Odenthal M: MicroRNA gene expression profile of hepatitis $C$ virusassociated hepatocellular carcinoma. Hepatology 2008, 47:1223-1232.

25. Budhu A, Ji J, Wang XW: The clinical potential of microRNAs. J Hematol Oncol 2010, 3:37.

26. Zhu K, Dai Z, Pan Q, Wang Z, Yang GH, Yu L, Ding ZB, Shi GM, Ke AW, Yang $X R$, Tao ZH, Zhao YM, Qin Y, Zeng HY, Tang ZY, Fan J, Zhou J: Metadherin promotes hepatocellular carcinoma metastasis through induction of epithelial-mesenchymal transition. Clin Cancer Res 2011, 17:7294-7302.

27. Ke AW, Shi GM, Zhou J, Huang XY, Shi YH, Ding ZB, Wang XY, Devbhandari RP, Fan J: CD151 amplifies signaling by integrin alpha6beta1 to PI3K and induces the epithelial-mesenchymal transition in HCC cells. Gastroenterology 2011, 140:1629-1641. e15.

28. Ijichi M, Takayama T, Matsumura M, Shiratori Y, Omata M, Makuuchi M: Alpha-Fetoprotein mRNA in the circulation as a predictor of postsurgical recurrence of hepatocellular carcinoma: a prospective study. Hepatology 2002, 35:853-860

29. Yin S, Li J, Hu C, Chen X, Yao M, Yan M, Jiang G, Ge C, Xie H, Wan D, Yang S, Zheng S, Gu J: CD133 positive hepatocellular carcinoma cells possess high capacity for tumorigenicity. Int J Cancer 2007, 120:1444-1450.

30. Sund M, Kalluri R: Tumor stroma derived biomarkers in cancer Cancer Metastasis Rev 2009, 28:177-183.

31. Trinchet JC, Chaffaut $C$, Bourcier V, Degos F, Henrion J, Fontaine $H_{\text {, }}$ Roulot D, Mallat A, Hillaire S, Cales P, Ollivier I, Vinel JP, Mathurin P, Bronowicki JP, Vilgrain V, N'Kontchou G, Beaugrand M, Chevret S: Ultrasonographic surveillance of hepatocellular carcinoma in cirrhosis: a randomized trial comparing 3- and 6-month periodicities. Hepatology 2011, 54:1987-1997.

32. Aghoram R, Cai P, Dickinson JA: Alpha-foetoprotein and/or liver ultrasonography for screening of hepatocellular carcinoma in patients with chronic hepatitis B. Cochrane Database Syst Rev 2012, 9:CD002799.
33. Bruix J, Llovet JM: Prognostic prediction and treatment strategy in hepatocellular carcinoma. Hepatology 2002, 35:519-524.

34. MCShane LM, Altman DG, Sauerbrei W, Taube SE, Gion M, Clark GM: Reporting recommendations for tumor marker prognostic studies (REMARK). J Natl Cancer Inst 2005, 97:1180-1184.

35. Singhal A, Jayaraman M, Dhanasekaran DN, Kohli V: Molecular and serum markers in hepatocellular carcinoma: predictive tools for prognosis and recurrence. Crit Rev Oncol Hematol 2012, 82:116-140.

36. IUS T: Detection of embryo-specific alpha-globulin in the blood serum of a patient with primary liver cancer. Vopr Med Khim 1964, 10:90-91.

37. Nagasue N, Inokuchi K, Kobayashi M, Saku M: Serum alpha-fetoprotein levels after hepatic artery ligation and postoperative chemotherapy: correlation with clinical status in patients with hepatocellular carcinoma. Cancer 1977, 40:615-618.

38. Tangkijvanich $\mathrm{P}$, Anukulkarnkusol N, Suwangool P, Lertmaharit $\mathrm{S}$, Hanvivatvong $O$, Kullavanijaya P, Poovorawan Y: Clinical characteristics and prognosis of hepatocellular carcinoma: analysis based on serum alphafetoprotein levels. J Clin Gastroenterol 2000, 31:302-308.

39. Zhou L, Liu J, Luo F: Serum tumor markers for detection of hepatocellular carcinoma. World J Gastroenterol 2006, 12:1175-1181.

40. El-Serag HB, Marrero JA, Rudolph L, Reddy KR: Diagnosis and treatment of hepatocellular carcinoma. Gastroenterology 2008, 134:1752-1763.

41. Shen Q, Fan J, Yang XR, Tan Y, Zhao W, Xu Y, Wang N, Niu Y, Wu Z, Zhou J, Qiu SJ, Shi YH, Yu B, Tang N, Chu W, Wang M, Wu J, Zhang Z, Yang S, Gu J, Wang H, Qin W: Serum DKK1 as a protein biomarker for the diagnosis of hepatocellular carcinoma: a large-scale, multicentre study. Lancet Oncol 2012, 13:817-826.

42. Yu B, Yang X, Xu Y, Yao G, Shu H, Lin B, Hood L, Wang H, Yang S, Gu J, Fan J. Oin W: Elevated expression of DKK1 is associated with cytoplasmic/ nuclear beta-catenin accumulation and poor prognosis in hepatocellular carcinomas. J Hepatol 2009, 50:948-957.

43. Shi RY YXR, Shen QJ YLX, XU YQSJ, Sun YF ZX, Wang ZZK, Qin WX TZ, Fan $\mathrm{JZJ}$ : High expression of dickkopf-related protein 1 is related to lymphatic metastasis and indicates poor prognosis in intrahepatic cholangiocarcinoma patients after surgery. Cancer 2012, in press.

44. Kladney RD, Cui X, Bulla GA, Brunt EM, Fimmel CJ: Expression of GP73, a resident Golgi membrane protein, in viral and nonviral liver disease. Hepatology 2002, 35:1431-1440.

45. Riener MO, Stenner F, Liewen H, Soll C, Breitenstein S, Pestalozzi BC, Samaras P, Probst-Hensch N, Hellerbrand C, Mullhaupt B, Clavien PA, Bahra M, Neuhaus P, Wild P, Fritzsche F, Moch H, Jochum W, Kristiansen G: Golgi phosphoprotein 2 (GOLPH2) expression in liver tumors and its value as a serum marker in hepatocellular carcinomas. Hepatology 2009, 49:1602-1609.

46. Mao $Y$, Yang $H, X u H$, Lu $X$, Sang $X$, Du $S$, Zhao $H$, Chen W, Xu Y, Chi T, Yang Z, Cai J, Li H, Chen J, Zhong S, Mohanti SR, Lopez-Soler R, Millis JM, Huang J, Zhang H: Golgi protein $73(\mathrm{GOLPH} 2)$ is a valuable serum marker for hepatocellular carcinoma. Gut 2010, 59:1687-1693.

47. Liebman HA, Furie BC, Tong MJ, Blanchard RA, Lo KJ, Lee SD, Coleman MS, Furie B: Des-gamma-carboxy (abnormal) prothrombin as a serum marker of primary hepatocellular carcinoma. N Engl J Med 1984, 310:1427-1431.

48. Takikawa Y, Suzuki K, Yamazaki K, Goto T, Madarame T, Miura Y, Yoshida T, Kashiwabara T, Sato S: Plasma abnormal prothrombin (PIVKA-II): a new and reliable marker for the detection of hepatocellular carcinoma. J Gastroenterol Hepatol 1992, 7:1-6.

49. Beale G, Chattopadhyay D, Gray J, Stewart S, Hudson M, Day C, Trerotoli P, Giannelli G, Manas D, Reeves H: AFP, PIVKAll, GP3, SCCA-1 and follisatin as surveillance biomarkers for hepatocellular cancer in non-alcoholic and alcoholic fatty liver disease. BMC Cancer 2008, 8:200.

50. Zhou J, Shi YH, Fan J: Circulating cell-free nucleic acids: promising biomarkers of hepatocellular carcinoma. Semin Oncol 2012, 39:440-448.

51. Cho WC: Circulating microRNAs as minimally invasive biomarkers for cancer theragnosis and prognosis. Front Genet 2011, 2:7.

52. Gao P, Wong CC, Tung EK, Lee JM, Wong CM, Ng IO: Deregulation of microRNA expression occurs early and accumulates in early stages of HBV-associated multistep hepatocarcinogenesis. J Hepatol 2011, 54:1177-1184

53. Llovet JM, Pena CE, Lathia CD, Shan M, Meinhardt G, Bruix J: Plasma biomarkers as predictors of outcome in patients with advanced hepatocellular carcinoma. Clin Cancer Res 2012, 18:2290-2300. 
54. Zhou J, Yu L, Gao X, Hu J, Wang J, Dai Z, Wang JF, Zhang Z, Lu S, Huang X, Wang Z, Qiu S, Wang X, Yang G, Sun H, Tang Z, Wu Y, Zhu H, Fan J: Plasma microRNA panel to diagnose hepatitis $B$ virus-related hepatocellular carcinoma. J Clin Oncol 2011, 29:4781-4788.

55. Minata M, Nishida N, Komeda T, Azechi H, Katsuma H, Nishimura T, Kuno M, Ito T, Yamamoto Y, Ikai I, Yamaoka Y, Fukuda Y, Nakao K: Postoperative detection of alpha-fetoprotein mRNA in blood as a predictor for metastatic recurrence of hepatocellular carcinoma. $J$ Gastroenterol Hepatol 2001, 16:445-451.

56. Lu J, Getz G, Miska EA, Alvarez-Saavedra E, Lamb J, Peck D, Sweet-Cordero A, Ebert BL, Mak RH, Ferrando AA, Downing JR, Jacks T, Horvitz HR, Golub TR: microRNA expression profiles classify human cancers. Nature 2005, 435:834-838.

57. Ventura A, Jacks T: microRNAs and cancer: short RNAs go a long way. Cell 2009, 136:586-591.

58. Calin GA, Croce CM: microRNA signatures in human cancers. Nat Rev Cancer 2006, 6:857-866.

59. Qu KZ, Zhang K, Li H, Afdhal NH, Albitar M: Circulating microRNAs as biomarkers for hepatocellular carcinoma. J Clin Gastroenterol 2011 45:355-360

60. Zhou SL, Dai Z, Zhou ZJ, Wang XY, Yang GH, Wang Z, Huang XW, Fan J, Zhou J: Overexpression of CXCL5 mediates neutrophil infiltration and indicates poor prognosis for hepatocellular carcinoma. LID. Hepatology 2012, doi:10.1002/hep.25907.

61. Wang $Y$, Chen $Y$, Ge N, Zhang L, Xie X, Zhang J, Chen R, Wang Y, Zhang B, Xia J, Gan Y, Ren Z, Ye S: Prognostic significance of alpha-fetoprotein status in the outcome of hepatocellular carcinoma after treatment of transarterial chemoembolization. Ann Surg Oncol 2012, 19(11):3540.

62. Scartozzi M, Faloppi L, Bianconi M, Giampieri R, Maccaroni E, Bittoni A, Del PM, Loretelli C, Belvederesi L, Svegliati BG, Cascinu S: The role of LDH serum levels in predicting global outcome in HCC patients undergoing TACE: implications for clinical management. PLOS One 2012, 7:e32653.

63. Kobayashi M, Ikeda K, Kawamura Y, Yatsuji H, Hosaka T, Sezaki H, Akuta N, Suzuki F, Suzuki Y, Saitoh S, Arase Y, Kumada H: High serum des-gammacarboxy prothrombin level predicts poor prognosis after radiofrequency ablation of hepatocellular carcinoma. Cancer 2009, 115:571-580.

64. Poon RT, Lau C, Pang R, Ng KK, Yuen J, Fan ST: High serum vascular endothelial growth factor levels predict poor prognosis after radiofrequency ablation of hepatocellular carcinoma: importance of tumor biomarker in ablative therapies. Ann Surg Oncol 2007, 14:1835-1845.

65. Pompili M, Rapaccini GL, de Luca F, Caturelli E, Astone A, Siena DA, Villani MR, Grattagliano A, Cedrone A, Gasbarrini G: Risk factors for intrahepatic recurrence of hepatocellular carcinoma in cirrhotic patients treated by percutaneous ethanol injection. Cancer 1997, 79:1501-1508.

66. Chung GE, Kim W, Lee JH, Kim YJ, Yoon JH, Lee JM, Lee JY, Kim SH, Kim D, Lee HS: Negative hepatitis B envelope antigen predicts intrahepatic recurrence in hepatitis $B$ virus-related hepatocellular carcinoma after ablation therapy. J Gastroenterol Hepatol 2011, 26:1638-1645.

67. Ishii H, Okada S, Nose H, Okusaka T, Nagahama H, Nakayama H, Nakasuka H, Yoshimori M: Predictive factors for recurrence after percutaneous ethanol injection for solitary hepatocellular carcinoma. Hepatogastroenterology 1996, 43:938-943.

68. Poon RT, Ng IO, Lau C, Zhu LX, Yu WC, Lo CM, Fan ST, Wong J: Serum vascular endothelial growth factor predicts venous invasion in hepatocellular carcinoma: a prospective study. Ann Surg 2001, 233:227-235.

69. Poon RT, Ho JW, Tong CS, Lau C, Ng IO, Fan ST: Prognostic significance of serum vascular endothelial growth factor and endostatin in patients with hepatocellular carcinoma. Br J Surg 2004, 91:1354-1360.

70. Wright LM, Kreikemeier JT, Fimmel CJ: A concise review of serum markers for hepatocellular cancer. Cancer Detect Prev 2007, 31:35-44.

71. Yamagamim H, Moriyama M, Matsumura H, Aoki H, Shimizu T, Saito T, Kaneko M, Shioda A, Tanaka N, Arakawa Y: Serum concentrations of human hepatocyte growth factor is a useful indicator for predicting the occurrence of hepatocellular carcinomas in C-viral chronic liver diseases. Cancer 2002, 95:824-834

72. Song BC, Chung YH, Kim JA, Choi WB, Suh DD, Pyo SI, Shin JW, Lee HC, Lee YS, Suh DJ: Transforming growth factor-beta1 as a useful serologic marker of small hepatocellular carcinoma. Cancer 2002, 94:175-180.
73. Zhao YM, Wang L, Dai Z, Wang DD, Hei ZY, Zhang N, Fu XT, Wang XL, Zhang SC, Qin LX, Tang ZY, Zhou J, Fan J: Validity of plasma macrophage migration inhibitory factor for diagnosis and prognosis of hepatocellular carcinoma. Int J Cancer 2011, 129:2463-2472.

74. Sun YF, Yang XR, Zhou J, Qiu SJ, Fan J, Xu Y: Circulating tumor cells: advances in detection methods, biological issues, and clinical relevance. J Cancer Res Clin Oncol 2011, 137:1151-1173.

75. Andreopoulou E, Cristofanilli M: Circulating tumor cells as prognostic marker in metastatic breast cancer. Expert Rev Anticancer Ther 2010, 10:171-177.

76. Chen TF, Jiang GL, Fu XL, Wang L, Qian H, Wu KL, Zhao S: CK19 mRNA expression measured by reverse-transcription polymerase chain reaction (RT-PCR) in the peripheral blood of patients with non-small cell lung cancer treated by chemo-radiation: an independent prognostic factor. Lung Cancer 2007, 56:105-114.

77. Attard G, Swennenhuis JF, Olmos D, Reid AH, Vickers E, A'Hern R, Levink R, Coumans F, Moreira J, Riisnaes R, Oommen NB, Hawche G, Jameson C, Thompson E, Sipkema R, Carden CP, Parker C, Dearnaley D, Kaye SB, Cooper CS, Molina A, Cox ME, Terstappen LW, de Bono JS: Characterization of ERG, AR and PTEN gene status in circulating tumor cells from patients with castration-resistant prostate cancer. Cancer Res 2009, 69:2912-2918.

78. Yun-Fan Sun YX, Xin-Rong Yang WG, Xin Zhang SQ, Ruo-Yu Shi BH, Jian Zhou JF: Circulating stem cell-like EpCAM + tumor cells indicate poor prognosis of hepatocellular carcinoma after curative resection. Hepatology 2013, in press.

79. Sengupta B, Siddiqi SA: Hepatocellular Carcinoma: Important Biomarkers and their Significance in Molecular Diagnostics and Therapy. Curr Med Chem 2012, 19(22):3722.

80. Behne T, Copur MS: Biomarkers for hepatocellular carcinoma. Int J Hepatol 2012, 2012:859076.

81. Shi GM, Ke AW, Zhou J, Wang XY, Xu Y, Ding ZB, Devbhandari RP, Huang $X Y$, Qiu SJ, Shi YH, Dai Z, Yang XR, Yang GH, Fan J: CD151 modulates expression of matrix metalloproteinase 9 and promotes neoangiogenesis and progression of hepatocellular carcinoma. Hepatology 2010, 52:183-196.

82. Farazi PA, DePinho RA: Hepatocellular carcinoma pathogenesis: from genes to environment. Nat Rev Cancer 2006, 6:674-687.

83. Hu J, Wang Z, Fan J, Dai Z, He YF, Qiu SJ, Huang XW, Sun J, Xiao YS, Song K, Shi YH, Sun QM, Yang XR, Shi GM, Yu L, Yang GH, Ding ZB, Gao Q, Tang ZY, Zhou J: Genetic variations in plasma circulating DNA of HBV-related hepatocellular carcinoma patients predict recurrence after liver transplantation. PLoS One 2011, 6:e26003

84. Morrison SJ, Kimble J: Asymmetric and symmetric stem-cell divisions in development and cancer. Nature 2006, 441:1068-1074.

85. Reya T, Morrison SJ, Clarke MF, Weissman IL: Stem cells, cancer, and cancer stem cells. Nature 2001, 414:105-111.

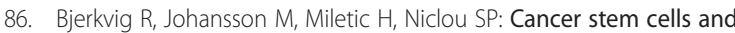
angiogenesis. Semin Cancer Biol 2009, 19:279-284.

87. Yang ZF, Ho DW, Ng MN, Lau CK, Yu WC, Ngai P, Chu PW, Lam CT, Poon RT, Fan ST: Significance of CD90+ cancer stem cells in human liver cancer. Cancer Cell 2008, 13:153-166.

88. Haraguchi N, Ishii H, Mimori K, Tanaka F, Ohkuma M, Kim HM, Akita H, Takiuchi D, Hatano H, Nagano H, Barnard GF, Doki Y, Mori M: CD13 is a therapeutic target in human liver cancer stem cells. J Clin Invest 2010, 120:3326-3339.

89. Yamashita T, Ji J, Budhu A, Forgues M, Yang W, Wang HY, Jia H, Ye Q, Qin LX, Wauthier E, Reid LM, Minato H, Honda M, Kaneko S, Tang ZY, Wang XW: EpCAM-positive hepatocellular carcinoma cells are tumor-initiating cells with stem/progenitor cell features. Gastroenterology 2009, 136:1012-1024.

90. Bremnes RM, Donnem T, Al-Saad S, Al-Shibli K, Andersen S, Sirera R, Camps C, Marinez I, Busund LT: The role of tumor stroma in cancer progression and prognosis: emphasis on carcinoma-associated fibroblasts and nonsmall cell lung cancer. J Thorac Oncol 2011, 6:209-217.

91. TIsty TD, Coussens LM: Tumor stroma and regulation of cancer development. Annu Rev Pathol 2006, 1:119-150.

92. George AL, Bangalore-Prakash P, Rajoria S, Suriano R, Shanmugam A Mittelman A, Tiwari RK: Endothelial progenitor cell biology in disease and tissue regeneration. J Hematol Oncol 2011, 4:24.

93. Gao Q, Qiu SJ, Fan J, Zhou J, Wang XY, Xiao YS, Xu Y, Li YW, Tang ZY: Intratumoral balance of regulatory and cytotoxic $T$ cells is associated 
with prognosis of hepatocellular carcinoma after resection. J Clin Oncol 2007, 25:2586-2593

94. Zhu XD, Zhang JB, Zhuang PY, Zhu HG, Zhang W, Xiong YQ, Wu WZ, Wang $L$, Tang ZY, Sun HC: High expression of macrophage colony-stimulating factor in peritumoral liver tissue is associated with poor survival after curative resection of hepatocellular carcinoma. J Clin Oncol 2008, 26:2707-2716.

95. Li YW, Qiu SJ, Fan J, Gao Q, Zhou J, Xiao YS, Xu Y, Wang XY, Sun J, Huang $X W$ : Tumor-infiltrating macrophages can predict favorable prognosis in hepatocellular carcinoma after resection. J Cancer Res Clin Oncol 2009, 135:439-449.

96. Kang N, Gores GJ, Shah VH: Hepatic stellate cells: Partners in crime for liver metastases. Hepatology 2011, 54:707-713.

97. Budhu A, Forgues M, Ye QH, Jia HL, He P, Zanetti KA, Kammula US, Chen Y, Qin LX, Tang ZY, Wang XW: Prediction of venous metastases, recurrence, and prognosis in hepatocellular carcinoma based on a unique immune response signature of the liver microenvironment. Cancer Cell 2006, 10:99-111.

98. Llovet JM, Real MI, Montana X, Planas R, Coll S, Aponte J, Ayuso C, Sala M, Muchart J, Sola R, Rodes J, Bruix J: Arterial embolisation or chemoembolisation versus symptomatic treatment in patients with unresectable hepatocellular carcinoma: a randomised controlled trial. Lancet 2002, 359:1734-1739.

99. Lo CM, Ngan H, Tso WK, Liu CL, Lam CM, Poon RT, Fan ST, Wong J: Randomized controlled trial of transarterial lipiodol chemoembolization for unresectable hepatocellular carcinoma. Hepatology 2002 35:1164-1171.

100. Kohles N, Nagel D, Jungst D, Durner J, Stieber P, Holdenrieder S: Relevance of circulating nucleosomes and oncological biomarkers for predicting response to transarterial chemoembolization therapy in liver cancer patients. BMC Cancer 2011, 11:202.

101. Pinato DJ, Sharma R: An inflammation-based prognostic index predicts survival advantage after transarterial chemoembolization in hepatocellular carcinoma. Transl Res 2012, 160:146-152.

102. Overdevest JB, Theodorescu D, Lee JK: Utilizing the molecular gateway: the path to personalized cancer management. Clin Chem 2009, 55:684-697.

103. Firer MA, Gellerman G: Targeted drug delivery for cancer therapy: the other side of antibodies. J Hematol Oncol 2012, 5:70

104. Chau GY, Lui WY, Chi CW, Chau YP, Li AF, Kao HL, Wu CW: Significance of serum hepatocyte growth factor levels in patients with hepatocellular carcinoma undergoing hepatic resection. Eur J Surg Oncol 2008, 34:333-338.

105. Hopfner M, Schuppan D, Scherubl H: Growth factor receptors and related signalling pathways as targets for novel treatment strategies of hepatocellular cancer. World J Gastroenterol 2008, 14:1-14.

106. Wilhelm SM, Adnane L, Newell P, Villanueva A, Llovet JM, Lynch M: Preclinical overview of sorafenib, a multikinase inhibitor that targets both Raf and VEGF and PDGF receptor tyrosine kinase signaling. Mol Cancer Ther 2008, 7:3129-3140.

107. Villanueva A, Llovet JM: Targeted therapies for hepatocellular carcinoma. Gastroenterology 2011, 140:1410-1426.

108. Sun HC, Tang ZY, Wang L, Qin LX, Ma ZC, Ye QH, Zhang BH, Qian YB, Wu ZQ, Fan J, Zhou XD, Zhou J, Qiu SJ, Shen YF: Postoperative interferon alpha treatment postponed recurrence and improved overall survival in patients after curative resection of HBV-related hepatocellular carcinoma: a randomized clinical trial. J Cancer Res Clin Oncol 2006, 132:458-465.

109. Mazzaferro V, Romito R, Schiavo M, Mariani L, Camerini T, Bhoori S, Capussotti L, Calise F, Pellicci R, Belli G, Tagger A, Colombo M, Bonino F, Majno P, Llovet JM: Prevention of hepatocellular carcinoma recurrence with alpha-interferon after liver resection in HCV cirrhosis. Hepatology 2006, 44:1543-1554.

110. Lo CM, Liu CL, Chan SC, Lam CM, Poon RT, Ng IO, Fan ST, Wong J: A randomized, controlled trial of postoperative adjuvant interferon therapy after resection of hepatocellular carcinoma. Ann Surg 2007, 245:831-842.

111. Cao B, Chen XP, Zhu P, Ding L, Guan J, Shi ZL: Inhibitory effect of interferon-alpha-2b on expression of cyclooxygenase-2 and vascular endothelial growth factor in human hepatocellular carcinoma inoculated in nude mice. World J Gastroenterol 2008, 14:6802-6807.
112. Ji J, Shi J, Budhu A, Yu Z, Forgues M, Roessler S, Ambs S, Chen Y, Meltzer PS, Croce CM, Qin LX, Man K, Lo CM, Lee J, Ng IO, Fan J, Tang ZY, Sun HC, Wang XW: MicroRNA expression, survival, and response to interferon in liver cancer. N Engl J Med 2009, 361:1437-1447.

113. D'Souza-Schorey C, Clancy JW: Tumor-derived microvesicles: shedding light on novel microenvironment modulators and prospective cancer biomarkers. Genes Dev 2012, 26:1287-1299.

doi:10.1186/2050-7771-1-10

Cite this article as: Zhu et al:: Biomarkers for hepatocellular carcinoma: progression in early diagnosis, prognosis, and personalized therapy. Biomarker Research 2013 1:10.

\section{Submit your next manuscript to BioMed Central and take full advantage of:}

- Convenient online submission

- Thorough peer review

- No space constraints or color figure charges

- Immediate publication on acceptance

- Inclusion in PubMed, CAS, Scopus and Google Scholar

- Research which is freely available for redistribution

Submit your manuscript at www.biomedcentral.com/submit
Ciomed Central 